\title{
LITERATURA E APRENDIZAGEM DA LEITURA
}

MOSS, J. F.; FENSTER, M. F. From literature to literacy. Newark: IRA, 2002. viii + 216
O uso educacional da literatura vai muito além do ensino-aprendizagem da própria literatura e da língua. Hoje, seu uso aparece associado ao ensino das mais diversas áreas do conhecimento e alcançando os vários níveis de escolaridade.

O livro aqui resenhado enfoca um dos aspectos mais tradicionais do uso da literatura - o ensino da leitura, mas o faz de uma forma enriquecedora.

Moss tem dupla formação, é bibliotecária e também professora de literatura da University of Rochester. Fenster é docente do ensino fundamental na The Harley School, em Rochester. Ambas aglutinaram suas competências e habilidades para estabelecer uma ponte de aprendizagem entre sala de aula e biblioteca, recorrendo à literatura para o ensino da leitura. Esta relação ainda precisa de estímulo e de pesquisa no exterior, no Brasil trata-se de uma necessidade ainda mais urgente.

Na Introdução é apresentada ao leitor a origem do trabalho decorrente da cooperação entre as autoras, as quais arrolam vários objetivos que pretenderam alcançar com o programa que resultou no livro, tudo para: dar oportunidade a que as crianças vivenciassem o prazer de crescer por meio da literatura, que desenvolvessem habilidades, motivação, estratégias e conhecimentos, tivessem experiências de pensar criticamente e para usarem a imaginação; para aprenderem a trabalhar em grupo; terem contato com os vários gêneros literários; terem contato com sua herança literária; para se envolverem com a escrita e leitura independentes; que a leitura se tornasse uma experiência humana; terem um contexto próprio para aprender sobre literatura; analisarem textos diversos 
e terem a oportunidade de estudar literatura com "olhos de escritores".

O livro está organizado em oito capítulos e inclui um índice de autores. Poderia ser enriquecido com um índice de conteúdo. A bibliografia citada é relativamente recente e predominantemente constituída por artigos de periódicos científicos.

O primeiro capítulo procura estabelecer uma ponte entre a teoria e a prática, expõe a base teórico-conceitual para a realização de um programa literatura/ aprendizagem da leitura, tendo por base muitas pesquisas já realizadas com crianças do ensino fundamental, as quais forneceram a base para o trabalho, independentemente do enfoque teórico. Assim, trata-se de um enfoque de unificação ou eclético-crítico. Algumas experiências com o uso da literatura e com as ligações intertextuais são apresentadas rapidamente, bem como trabalhos sobre: impacto da literatura nos leitores, leitura em voz alta, tecnologias para melhor uso da literatura etc. O denominador comum deste como dos demais capítulos é a integração da sala de aula com a biblioteca.

Os capítulos seguintes descrevem várias estratégias utilizadas, cuidadosamente testadas.

O segundo capítulo lembra em seu título o livro usado como ponto de partida, sobre um cão feliz. São arroladas 10 estra- tégias trabalhadas com as crianças a partir do texto literário, além de introduzi-las nos gêneros literários. Talvez fosse conveniente uma rápida explicação destas estratégias já que algumas podem não ser conhecidas de todos os leitores ou pelo menos, explicitar junto a elas uma bibliografia de apoio. Mostra como introduzir um texto e explorá-lo quanto ao gênero, fazendo análises comparativas, usando inferências, fazendo desenhos. É imprescindível fazer avaliações constantes e prestar atenção aos textos que as crianças escolhem.

O assunto continua no capítulo seguinte no qual são exploradas as figuras principais do texto, sejam pessoas, sejam animais, relacionando-as com os gêneros literários, textos realísticos e de ficção, o uso de legendas. Recomenda registros cuidadosos e a avaliação. Este como os demais capítulos apresentam diálogos das autoras com as crianças que são muito ilustrativos.

O Capítulo 4 apresenta como trabaIhar com a criança a classificação dos livros, ou seja, as possibilidades de tipologia dos livros, como utilizar as classificações, sempre tendo por base a avaliação, o desenvolvimento da criticidade e a criação na classe e na escola de uma comunidade de leitores. Introduz o aluno do ensino fundamental na análise literária, na caracterização dos autores (estilo de escritor) e artistas (ilustradores). É imprescindível ajudar o 
aluno a fazer análises comparativas e ligações intertextuais.

A transformação do texto é objeto da atenção do Capítulo 5, a possibilidade de mudar o texto surpreende e motiva a criança, pode ser um motivo literário. Neste contexto é preciso que a criança esteja atenta ao desenvolvimento do caráter, das características, dos vários figurantes e personagens da história, para garantir consistência nas mudanças introduzidas. As estratégias precisam ser aprendidas de modo a assegurar a presença dos sentimentos que se pretende gerar no leitor. O texto é ilustrado por redações de crianças que modificaram o original usando várias estratégias.

O capítulo seguinte aprofunda a transformação trabalhando este aspecto do prisma da complexidade humana, de sua subjetividade (mundo interior), das qualidades humanas. Ao trabalhar estes aspectos é preciso que a criança esteja atenta aos seus objetivos e os reveja, se necessário, ao transformar o texto. Isto implica em manter seu crescimento e satisfação pessoal com o que está fazendo. É importante que explore, faça pesquisas e descubra os vários aspectos do livro que está modificando. O uso do pensamento crítico é fundamental e consoante com isto está a atuação da comunidade de leitores que podem fornecer pistas, parâmetros e cooperação. Esta atividade pode ser feita com todos os gêneros literários e ser um meio para explorar a herança literária da região ou do país. Também aqui é importante respeitar os interesses pessoais dos jovens leitores e estimulá-los para que sejam leitores independentes. Neste contexto, é importante fazer a relação entre literatura e experiência de vida. $A$ análise literária e o conhecimento do autor e artista podem ser de grande valia.

A escrita em cooperação vem ganhando espaço entre as tecnologias de ensino, destacando-se por sua eficiência. Ela também foi cuidada nos estudos de Moss e Fenster (Capítulo 7) que começam informando como fazer o preparo do aluno para este tipo de atividade. São propostas questões iniciais que orientam o grupo para produzir o trabalho. Elas são diretrizes para definir história, personagens, problema(s), trama etc. Em seguida, tratam propriamente da produção de texto, sua redação e ilustração. Como exemplo apresenta um produto gerado em colaboração com o título A Biblioteca Mágica que por si mesmo reflete o papel da biblioteca e bibliotecário no programa.

O capítulo final apresenta uma análise da interação biblioteca-sala de aula, que deveria ser lido com atenção por bibliotecários e docentes. Concluem que a colaboração entre bibliotecária e professor é enriquecedora e as autoras relatam que ambas ganharam com a experiência. Não é possível generalizar para situações em 
que não se tenha bibliotecários e professo-

res com a devida formação e motivação.

Enfocam também o impacto nas crianças que foram envolvidas no programa destacando o desenvolvimento que tiveram em leitura e escrita, individual e em cooperação. O efeito do trabalho realizado na $1^{\text {a }}$ série estava muito evidente na $3^{\mathrm{a}}$ série.

Trata-se de um trabalho muito rico que estimula a integração da biblioteca com a sala de aula, segue estratégias muito úteis e interessantes não apenas para o ensino mas também para a pesquisa.

\section{Geraldina Porto Witter}

Universidade de Mogi das Cruzes

Pontifícia Universidade Católica de Campinas

\section{Tit/e}

Literature and reading learning

\section{Título}

Literatura y aprendizaje de la lectura 